\title{
The Celts and the Slavs: \\ On K. H. SChMidT's Hypothesis ON THE \\ Eastern Origin of the Celts
}

\author{
$\uparrow_{\text {VIKTOR KALYGIN }}^{1}$
}

\section{Introduction}

Language links between Celtic and Slavic branches of Indo-European are much less studied than, for instance, those between Celtic and Italic. Research in this area is mostly carried out among Slavic scholars, of whom there are but a few. One of the rare Celtic scholars, on the other hand, to pay attention to Celto-Slavic links and contacts is K. H. Schmidt, whose treatment of the Slavic evidence is impeccable. His 1985 article (Schmidt 1985) - unfortunately, mostly inaccessible to Russian scholars - remains one of the major contributions in this field. In the present paper, I would like to draw particular attention in what follows to a number of points in Schmidt's theory.

It is necessary to analyse relations between Celtic and other branches of Indo-European in their dynamics. In other words, we must pay attention to absolute, as well as relative chronology, and consider that relations between Celts and Italics, Slavs etc. were different at different moments of time. Trivial as it may seem, this observation points to an area of study that has been rather poorly explored to date. The present article is an attempt to create a chronological scale for possible Celto-Slavic contacts.

\section{Celtic and Slavic isoglosses and the periods of Celto-Slavic contact}

From the point of view of traditional Indo-European scholarship, Celtic languages belong to the Western group of Indo-European dialects; the main criterion for this division is, of course, the 'centum vs satzm' opposition. In this respect, Celtic, as well as Italic and Germanic, does not have a distinction between $* k$ and $* \hat{k}$.

The majority of isoglosses which link Celtic and Slavic (and other Indo-European languages once spoken in ancient Europe) are part of the common European language material which ultimately goes back to the

\footnotetext{
The draft translation from the Russian original was provided by Dr. Natalia O'Shea, Trinity College Dublin.
} 
THE CELTS AND THE SLAVS:

ON K. H. SCHMIDT'S HYPOTHESIS ON THE EASTERN ORIGIN OF THE CELTS

common Indo-European past. But it would be wrong to place them all on one particular chronological level, for example, Proto-Indo-European. Similarities between Celtic and Slavic are not only defined by historical circumstances, but may point to regional and chronological specifics of the development of individual branches of Indo-European in Europe. I am now talking about a number of archaic features which cannot constitute IndoEuropean heritage, but evolved in the course of later language contacts.

For example, the Gaulish future with suffix -sie-/-sio- is a good piece of evidence pointing to very ancient links between Proto-Celts and speakers of Eastern Indo-European dialects, Proto-Slavs among them, as was convincingly shown by K. H. Schmidt (1992; 1996): Gaul. 3 Sg. Fut. bisiet 'he will be' OCSl. byšęšteje 'the future', cf. Skt. kar-i-syá-ti 'he will do',

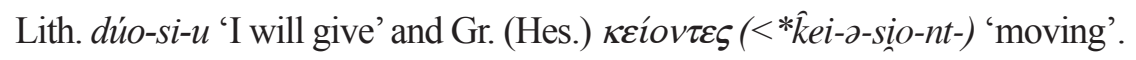

Thus, according to Schmidt, we can postulate the first period to which common features between Celtic and Eastern Indo-European go back. These features are: a) the aforementioned -sie-/-sio-future forms, cf. Gaul. 3 Sg. Fut. bisiet 'he will be' OCS1. byšęšteje 'the future'; b) relative pronoun *ios, also known of in Greek, Phrygian and Indo-Iranian; c) Old Irish sigmatic and asigmatic ${ }^{2}$ reduplicated futures which correspond directly to Indo-Iranian reduplicated desiderative: OIr. $3 \mathrm{Sg}$. Fut. -céla 'he will conceal' of ceilid $<* k e \chi l a \bar{~}<* k i k l a \bar{a}<* k i-k l h-s e-t i$, Skt. $3 \mathrm{Sg}$. Desr. cikirșati of kar- 'make, do'. These features are absent in Italic, which may mean that there were no close contacts between Celts and Italics at that time. Correspondences in the religious vocabulary, mentioned by Vendryes (1915), may go back to this time, too. This period ended, apparently, with the formation of a Proto-Celtic ethnos.

The second period shows us common features in Celtic, Hittite, Tocharian and Italic. These are: a) verbal deponent endings in $-r ; b$ ) a handful of correspondences, such as OIr. éc 'death' Hitt. hencan 'plague', OIr. reb 'game' Toch. A rape 'music'. These correspondences may point to a certain movement within the language continuum, which eventually resulted in Celtic drifting away from Eastern Indo-European dialects.

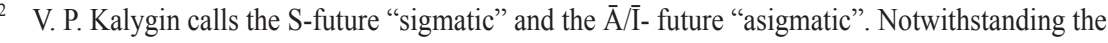
fact that both go back to desiderative formation with sigmatic suffix, and that the apparent divergence between the two only occurs in Insular Celtic due to lenition and subsequent loss of 's' in vocalic environment, I decided to preserve Kalygin's terminology in my translation of the article (N. O'Shea)
} 
The typical features of the third period are as follows: a) distant assimilation $p \ldots k^{u}>k^{u} \ldots k^{u}$ (Lat. quinque, OIr. cóic, W. pimp $\sim$ Skt. páñca 'five'); b) ending $-\bar{l}$ in the Genitive of thematic stems: Lat. viri $\sim$ OIr. fir $<$ *uirī; c) a few common words: *kūlu/i- 'back', *mātu/i- 'good' and a couple of others; d) S- and A- subjunctives (Lat. feram $\sim$ OIr. bera, Archaic Lat. faxim $\sim$ OIr. tíasu); ${ }^{3}$ superlative suffix *-sam- (Lat. maximus $\sim$ OIr. nessam,

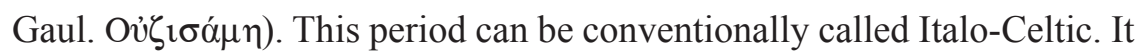
seems fairly close to the period of Celto-Germanic connections, such as *oitos 'oath', *orbhio 'heritage' etc.).

It is not easy to say whether the aforementioned Celto-Italic and CeltoGermanic connections belong to a particular historical period (or periods) or whether they rather go back to the so-called Ancient European language continuum. The latter appears to be the most likely explanation on the basis of hydronyms and some common vocabulary ( *teut $\bar{a}$ 'tribe', *mor(i)'sea', *peisk- 'fish' etc.). On other levels of linguistic development, Ancient European shows long vowel shortening, studied by V. A. Dybo (Dybo 1961), which applies to Germanic as well. ${ }^{4}$ It is possible, too, that ProtoSlavs partially belonged to this continuum. The Ancient European continuum ceased to exist due to a complex pattern of tribe migration. ${ }^{5}$

The new period of Celto-Slavic contacts starts in the fourth century B. C. in the Carpathians and Silesia. Archaeological evidence shows a lengthy and intensive interaction between Celtic and Slavic tribes in Silesia and north of the Carpathians. Celts dwelled in Silesia at the turn of the fourth century B.C., and in the next century they crossed the Carpathians and entered the Vistula region. One of the early Slavic archaeological cultures, called the 'Podkloshevy grave culture' which existed in this area since ca. 400 B. C., shows strong Celtic influence. There were a number of artefacts of Celtic origin among the artifacts found in these graves, such as brooches, swords, axes, armbands and coins. The Celtic influence gradually transformed the Podkloshevy grave culture into Pržeworian culture. There are pottery ovens of the Celtic type to be found in Pržeworian villages; the Slavs

\footnotetext{
3 V. P. Kalygin maintained the view that the Celtic $\bar{A}$-subjunctives corresponded directly to those in Italic; for some reason he did not agree with C. Watkins' theory which links them to the sigmatic aorist subjunctive (N. O'Shea).

4 V. A. Dybo (oral communication).

5 As for southern regions, it is worth noting that when Ugrian tribes came to Pannonia, they started calling the local Romanised population by the word tót, which, of course, goes back to Celtic *teutā.
} 
THE CELTS AND THE SLAVS:

ON K. H. SCHMIDT'S HYPOTHESIS ON THE EASTERN ORIGIN OF THE CELTS

adopted a few elements of Celtic technology in metalwork (Sedov 2002: 76ff.). It is interesting, though, that the borrowing of crafts did not, as it seems, entail borrowing of corresponding words. Let us analyse a number ofCeltic metalwork terms and compare them to the relevant Slavic material in order to find the reason for this phenomenon.

In this respect the dialects of Western Gaul display the following characteristics:

a) Gaul. *meina 'ore, raw metal' (form reconstructed on the basis of evidence from Romance languages) corresponds to OIr. méin with the same meaning; both of these go back to Proto-Celtic *meina $\bar{a}$, whereas the preform for the Welsh cognate, mwyn, can be reconstructed as *meini-; some scholars believe that this lexeme is a derivative of IE. *smei- 'cut, work with sharp tools' (cf. Goth. aisa-smipa 'blacksmith', ON. smiðr 'smith, carpenter'; OCSl. médb 'copper'?); this word, inherited from Gallo-Roman, exists now as French mine, Spanish and Italian mina and English (borrowed from French) mine. ${ }^{6}$

b) Gaul. stagnum 'alloy of silver and lead', known from Plinius; connections unclear; inherited into French étain through Vulgar Latin stannum.

c) Gaul. enemo- 'anvil' corresponds to OBret. anemn and OIr. indeóin 'id.', not attested outside Celtic, etymology unclear.

d) Gaul. cellos 'hammer', as can be segmented from a theonym Sucellos 'well-striking' < *keldo-, goes back to IE. *keld- 'strike'.

Evidence from Insular Celtic, mostly Old Irish, allows us to make a few additions to this list:

a) berbaid 'melts, fuses' < 'boils', from IE. * $b^{h} e r$ - 'boil, bubble';

b) bolg 'bellows' < 'sack, bubble', cf. Gaul. *bulga, 'leather sack', Goth. balgs 'wineskin', Lat. follis 'leather bag';

c) bruth 'bloom, loop', from *bhru-to-, IE. *bhreu- 'boil';

d) claidid 'mines ore' < 'digs', etymology unclear;

e) ord 'hammer', etymology unclear, not attested outside Celtic;

f) slaidred 'scale, dross', etymology unclear, not attested outside Celtic;

g) teine 'furnace' < 'hearth' < 'fire', a common Celtic word which has cognates in other branches of Indo-European, cf. Av. tafno.

As one can see from this list, Celtic metalwork vocabulary has nothing to do with the equivalent Slavic vocabulary, which mainly consists of Slavic innovations, such as kuznya 'smithy', ruda 'oar', molot 'hammer', mekh 'bellows' etc. (cf. Zhuravlev 1996: 134-138).

\footnotetext{
Cf. LEIA: M-29.
} 
The explanation for the absence of linguistic evidence for Celto-Slavic metalwork connections may lie in historico-cultural and ecological circumstances: the end of the fourth century A.D. in Europe was marked by a drastic fall in temperature, which entailed flooding of a considerable amount of land, which, in turn, reduced the area suitable for agriculture. On the other hand, the Roman Empire that used to help Romanised provincial cultures, such as Pržeworian culture, fell; the invasion of the Huns cut short the development of cultures north of the Black Sea and north of the Carpathians, which entailed their barbarisation; these cultures could not keep the high standards of crafts which they maintained in the times of contact with highly developed cultures. These factors, as well as the wave of migration at that time, could well have led to a breakdown in cultural tradition and, therefore, a change of technical vocabulary. A new Prague-Korchakow culture was formed in the south of the Pržeworian area (Sedov 1998: 279-280).

This was the end of Celto-Slavic contacts, but the preceding period had left a number of traces in the vocabulary of Slavic languages. It is necessary to note, however, that it is not always possible to place items of this common vocabulary in time; that would require a more detailed study.

\section{Celto-Slavic correspondences and their possible explanations}

We will adduce now a number of the most well-known correspondences, as given by K. H. Schmidt, J. Pokorny, A. Falileyev etc.:

1. Identical ablaut grade:

a) *krauo- 'roof': OIr. cró, 'enclosure, shed', W. crau 'sty, stockade',

OCSl. krovъ, Russ. krov 'roof';

b) *mls-: Celt. *mlas-to (OIr. mlas, 'taste', W. blas 'id.') Russ. molsat' 'to suck';

c) *iar(o)-: Celt. *iaro- (OIr. éirín, 'chick, pullet', W. iar, 'hen', Bret. yar, 'id.', Gaul. iaros 'id.') Proto-Slav. jarıka 'a young animal, a yearling' (Bulg. jarka 'chicken');

e) *uōlo-: OIr. fál 'enclosure, fence, hedge' Russ. val 'bank';

f) *su-doru-: MidW. hydder 'very stubborn, steadfast' $\sim$ Russ. zdorovyj 'healthy';

g) *krou-k-: OIr. crúach, found in theonyms Crom Crúach, Cenn Crúach, as well as ethnonym Crúachain OCSl. krukъ 'raven, crow', OPol. kruk, 'id.', Russ. dial. kruk 'raven'; this correspondence between Slavic and Celtic jeopardises the theory of Slavic krukb being a derivative from the enantiosemic verb krukati 'to croak'. 
THE CELTS AND THE SLAVS:

ON K. H. SCHMIDT'S HYPOTHESIS ON THE EASTERN ORIGIN OF THE CELTS

2. Different ablaut grades:

a) Celtic *krd-su- 'girth, belt' (OIr. cris 'belt, waist', W. crys 'shirt', gwregys 'belt') Slavic *kerd-so (Russ. cheresla 'hips');

b) Celtic *lāto 'heat (of animals)' (OIr. láth, W. llawd) Slavic *lēti'heat (of animals)' (Ukr. lit' 'to spill'); we should mention here the correspondence between Celtic *lati- 'day' and Slavic *lěti-/lěto 'Summer'.

3. Other correspondences:

a) *tātis 'thief': OIr. táid OCSl. tatb < IE. *(s)tā-;

b) *ankat-: Celtic *ankato- (OIr. écath 'fish-hook', W. angad 'grasp, hand')

$\sim$ Slavic *okati- (Russ. ukotr 'hook') < IE. *ank- 'to bend';

c) *morui 'ant': OIr. moirb, MidW. myrion (Pl.) OCSl. mravi;

d) *bei-ko-/beko- 'bee': OIr. bech OCSl. bъčela;

e) OIr. escaid/aiscid 'seeks' Russ. iskat' 'to seek, to look for';

f) *kagn-: OIr. cáin 'rule, regulation, law' OCSl. kaznb 'punishment', Russ. kazn' '(capital) punishment, execution' < IE. *kāgnis/kögnis;

g) OIr. gábud 'danger, fear' $\sim$ Russ. zabota 'concern, worry';

h) OIr. theonym Macha ORuss. Mokošb (both from *Mokosiā);

i) W. gweryd 'earth, soil' $\sim$ Russ. vereteja 'a piece of arable land'.

As far as possible borrowings are concerned, there is a number of interesting suggestions, as given by Martynov (Martynov 1983: 21-29), Trubachov (Trubachov 1983: 243) and Bernstein (Bernstein 1961: 94-95). Not all of them are viable and credible, though. For example, Martynov suggests that we should look for a Celtic origin of a Proto-Slavic word * br'uxo 'belly'; if we identify its precursor as OIr. brú 'abdomen, belly' < *brusō, the palatalised $r$ ' of the Slavic form defies explanation. On the contrary, one could posit a preform *breusno(n), which would obviously yield a palatalised $r$ '. One could mention such forms with non-palatalised $r$, as Proto-Slavic *brusna (ORuss. brusny 'feature, limb' $\sim$ OW. \& Bret. bronn 'chest, bosom' < *brusnā, OIr. bruinne 'breast, bosom' < *brusnio-).

One of the substantial difficulties that a Celto-Slavic scholar is constantly faced with is that we have only very little evidence of any Celtic language which could have been in contact with Slavic. Of course, it is highly inappropriate to ascribe features of Irish or other Western Celtic languages to the language of the Celts who lived in Bohemia or the Carpathians. Therefore, one could hardly explain the lenition of the initial $s^{-}>h$ - in the ethnonym Helvetii by the fact that similar lenition occurs in British Celtic: the features being compared are separated by hundreds of 
miles in space and several centuries in time. ${ }^{7}$ The explanation of Russian boyarin 'a lord' as a borrowing from Old Irish (sic!) bó aire 'a stockmaster' is a striking nonsense. Another tentative hypothesis is that of Slavic kon' 'horse' being a simplification of Celtic *konk-, which allegedly can be found in OIr. cuing 'yoke' and a place-name in Spain, Concani. On the other hand, a substrate place-name in Poland, Pieniny, looks a good parallel with British Pennine, and both of these can be derived from the Celtic word for head, *penno- (Trubachov 2002: 46). ${ }^{8}$

Celto-Slavic relations seem to have been more diverse and intriguing than they are normally considered to have been. We believe that a thorough study of Polish and Czech dialectal vocabulary, as well as a meticulous (though mostly relative) dating of common elements may prove to be useful in this respect. From the point of view of morphology, which remains virtually unaddressed in our case, one could perform a comparative study of the development of the verbal system - more precisely, of the tense and aspect system. Phonology may also provide material worth investigating: a prosodic interpretation of palatalisation and the theory that Proto-Slavic and Proto-Celtic started their consonantal systems not on the three-grade basis $T-D-D h$, but on a two-grade basis $T-D$, which is believed to reflect a more archaic state of Indo-European (Herzenberg 1979: 83).

Institute of Linguistics, Russian Academy of Sciences, Moscow

\footnotetext{
See further discussion of the development of IE * $p$, Gaulish $s$, and other related issues in Falileyev 2006 [Eds.].

8 This equation sounds dubious, too, as we have no information as to whether Eastern Celtic was Q- or P-Celtic; given that change $* k^{u}>* p$ is not the earliest development in terms of relative chronology of Celtic sound-change, it seems tentative to ascribe the $p$-feature to Celtic spoken in Eastern Europe. Moreover, as Polish colleagues inform me, there is a perfectly neat Slavic etymology for the toponym Pieniny, deriving it from the word pena 'foam', which corresponds to the fact that there are actual mountain rivers in the place in question (N. O'Shea).
} 
THE CELTS AND THE SLAVS:

ON K. H. SCHMIDT'S HYPOTHESIS ON THE EASTERN ORIGIN OF THE CELTS

\title{
SUMMARY:
}

\section{Виктор ПАВЛОВич КАЛЫГиН}

\section{КЕЛЬТЫ И СЛАВЯНЕ: К ГИПОТЕЗЕ К. Х. ШМИДТА О ВОСТОЧНОМ ПРОИСХОЖДЕНИИ КЕЛЬТОВ}

\begin{abstract}
АВТОР Р АССМАТР ИВАЕТ ЛИНГВИСТИЧЕСКИЕ СВЯЗИ МЕЖДУ КЕЛЬТСКОЙ И СЛАВЯНСКОЙ ВЕТВЯМИ ИНДО-ЕВР ОПЕЙСКОЙ ГРУППЫ ЯЗЫКОВ, СЛЕДУЯ ПР ИНЦИПАМ, ПОЛОЖЕННЫМ В РАБОТАХ К. Х. ШМИДТА. ОСОБОЕ ВНИМАНИЕ УДЕЛЯЕТСЯ ОТНОСИТЕЛЬНОЙ ХРОНОЛОГИИ ВОЗМОЖНЫХ КОНТАКТОВ МЕЖДУ КЕЛЬТСКИМИ И СЛАВЯНСКИМИ ПЛЕМЕНАМИ В КОНТЕКСТЕ ЛИНГВИСТИЧЕСКОЙ СИТУАЦИИ, СУЩЕСТВОВАВШЕЙ В ЕВР ОПЕ В ТО ВРЕМЯ.
\end{abstract}

